\title{
Enhanced plasticity and superplasticity of ultrafine-grained nickel
}

\author{
A. P. Zhilyaev \\ AlexZ@anrb.ru \\ Institute for Metals Superplasticity Problems, RAS, 39 Khalturin, Ufa, 450001, Russia
}

\begin{abstract}
Although superplasticity has intensively been studied for half century, few observations have been reported for pure metals due to fast grain growth at temperatures required for superplasticity. With developing of nanocrystalline materials, there was a hope that superplasticity could be obtained in a number of pure metals. Indeed, low temperature superplasticity in pure nickel was reported in pioneering work in 1999, later superplastic feature of nanonickel was attributed to sulfur presence in grain boundaries. Recently, it was concluded that superplasticity it is not related to the presence of sulfur at grain boundaries or a liquid phase at grain boundaries. Thereby, the phenomenon of superplasticity in pure metals is still far away for our understanding and it requires future work. This report is devoted to reassessment of superplastic behavior of nano-nickel and it provides new results on enhanced plasticity of pure nickel processed by HPT consolidation of rapid quenched ribbons. Bulk ultrafine-grained nickel was successfully processed by RT consolidation of rapid quenched ribbons using high-pressure torsion. RQ nickel possesses equiaxed grain structure with mean grain size of $1-2 \mu \mathrm{m}$ showing well defined grain boundaries. Upon HPT consolidation mean grain size of $\sim 0.2 \mu \mathrm{m}$ and high dislocation density have been achieved. However, consolidated $\mathrm{Ni}$ specimens show enhanced plasticity $>140 \%$ at testing temperature of $450^{\circ} \mathrm{C}$ and strain rate of $10^{-3} \mathrm{~s}^{-1}$. No superplastic regime has been attained for given testing conditions.
\end{abstract}

Keywords: nickel, superplasticity, electrodeposition, rapid quenched ribbons, high-pressure torsion, consolidation

\section{Повышенная пластичность и сверхпластичность ультрамелкозернистого никеля}

Хотя сверхпластичность интенсивно исследовалась в течение полувека, только небольшое количество данных было опубликовано для случая чистых металлов ввиду быстрого роста зерен в них при температурах, необходимых для сверхпластичности. С разработкой нанокристаллических материалов появилась надежда, что сверхпластичность может быть получена в ряде чистых металлов. Действительно, низкотемпературная сверхпластичность была обнаружена в пионерской работе в 1999 г.; позднее сверхпластическое поведение наноникеля было объяснено наличием серы в границах зерен. Недавно было выяснено, что сверхпластичность не связана с серой в границах зерен или жидкой фазой в границах зерен. Таким образом, явление сверхпластичности в чистых металлах все еще далеко от понимания и требует дальнейшего исследования. Данная работа посвящена пересмотру сверхпластического поведения наноникеля и приводит новые данные о повышенной пластичности чистого никеля полученного путем консолидации методом кручения под высоким давлением (КВД) быстрозакаленных лент. Путем консолидации быстрозакаленных лент методом КВД был получен объемный ультрамелкозернистый никель. Быстрозакаленный никель имеет равноосную зеренную структуру со средним размером зерен 1-2 мкм и хорошо сформированными границами зерен. После консолидации КВД достигнут средний размер зерен около 0.2 мкм и высокая плотность дислокаций. Однако консолидированные образцы Ni проявляют высокую пластичность (более 140\%) при температуре испытаний $450^{\circ} \mathrm{C}$ и скорости деформации $10^{-3} \mathrm{c}^{-1}$. Для данных условий сверхпластического режима не было достигнуто.

Ключевые слова: никель, сверхпластичность, электроосаждение, быстрозакаленные ленты, кручение под высоким давлением, консолидация

\section{Introduction}

A strong refinement of microstructure in metals and alloys by equal channel angular pressing (ECAP) and highpressure torsion (HPT) provides a potential for attaining new and extraordinary properties $[1-3]$, which are grain size dependent. Bulk nanocrystalline (NC) and ultrafinegrained (UFG) materials provide a good opportunity to study a scalability of physical and mechanical properties to nanoscale range. Superplasticity is known as strong grain 
size dependent phenomenon. It is manifested as an ability of a material to sustain large plastic deformation. Necessary conditions for superplasticity observation are a stable finegrained microstructure and a temperature higher a half of the melting temperature. The generalized constitutive equation for superplasticity links the flow stress and strain rate:

$$
\dot{\varepsilon}=A \frac{D G b}{k T}\left(\frac{b}{d}\right)^{p}\left(\frac{\sigma}{E}\right)^{n},
$$

where $\varepsilon$ is the strain rate, $D$ is the appropriate diffusivity (lattice or grain boundary), $G$ is the shear modulus, $b$ is the Burger's vector, $k$ is the Boltzmann's constant, $T$ is the test temperature, $d$ is the grain size, $p$ is the grain size exponent and $\sigma$ is the applied stress and $1 / n$ is the strain rate sensitivity. This equation suggests that NC and UFG materials, at constant strain rate, may be superplastic at significantly lower temperatures than their coarse-grained counterparts, which would reduce the problem of grain growth during deformation.

In pioneering work [4-7], it was reported that superplasticity in electrodeposited nanocrystalline nickel can be achieved at $350^{\circ} \mathrm{C}$, which is 0.36 of the melting point $\left(\mathrm{T}_{\mathrm{M}}\right)$, the lowest normalized superplastic temperature reported for any crystalline material. A maximum elongation of $895 \%$ was obtained at $0.4 \cdot \mathrm{T}_{\mathrm{M}}$, which is a large reduction in temperature and increase in elongation over the previously reported best result for cold rolled nickel [4] of $250 \%$ elongation at $0.75 \cdot \mathrm{T}_{\mathrm{M}}$. One can expect similar results can be observed in nanostructured materials processed by high-pressure torsion straining that leads to significant grain refinement. However, numerous attempts to attain superplasticity in pure metals processed by high-pressure torsion were unsuccessful although in many UFG alloys, superplastic behavior at substantially low temperature and at high strain rate was found [5,6], pure copper and nickel refined by HTP did not demonstrated noteworthy plasticity. This controversy leads to discussable conclusion in [8] that superplasticity in electrodeposited nickel induced by sulfur segregating in grain boundaries. However, later it was shown clearly for electrodeposited nickel with different contents of sulfur [9-11] that there is no influence of sulfur content on superplastic behavior during tensile testing. Certainly in many cases commercial purity nickel with some retained sulfur was employed for HPT processing and consequent tensile testing. In those specimens no superplastic behavior has been detected. Another method of processing ultrafine-grained structure is the HPT consolidation of rapid quenched (RQ) nickel ribbons. It was shown earlier [12] that bulk specimens with fine structure of grain size of about $0.2 \mu \mathrm{m}$ or less can be processed by this method. The aim of this paper to study tensile properties of HPT consolidated RQ nickel at elevated temperatures and discuss the results obtained in light of possibility to achieve superplacticity in pure metals.

\section{Experimental Procedure and Material}

High-purity (99.99\%) nickel was selected for this investigation. Full details of the experimental procedure for rapid quenching were described earlier [12]. Briefly, ribbons of pure nickel were prepared by melt spinning under an argon atmosphere using a copper wheel with a rotation speed of $\sim 10^{3}$ revolutions per minute. These nickel ribbons of $\sim 30 \mu \mathrm{m}$ in thickness and $3 \mathrm{~mm}$ in width were shiny and of good quality, the thickness and the width were maintained constant over long lengths and there was no evidence for any holes, protruding inclusions or crystals or any rough edges.

A consolidation was performed using constraint HPT (Fig. 1) at room temperature at applied load of $6 \mathrm{GPa}$ for 6 whole revolutions. Final specimens had a disk shape of $\sim 10$ $\mathrm{mm}$ in diameters and about $0.5 \mathrm{~mm}$ in thickness. Further details can be found elsewhere [3,12].

Tensile specimens having a gage length and width of 1.0 $\mathrm{mm}$ and a nominal thickness of $0.5 \mathrm{~mm}$ were electro-discharge machined from nickel disk (Fig. 2). Testing was conducted at constant strain rate $10^{-3} \mathrm{~s}^{-1}$ using a laboratory constructed bench-top tensile machine having $5 \mu \mathrm{m}$ displacement and $10-20 \mathrm{~g}$ load resolution. Samples were heated at $50^{\circ} \mathrm{C} \mathrm{min}^{-1}$ to the test temperature, which was controlled to $\pm 1^{\circ} \mathrm{C}$. Final elongation was measured in the gage length in order to eliminate contribution from deformation in the specimen heads. Microstructural characterization of material under study was performed by transmission electron microscopy TEM.

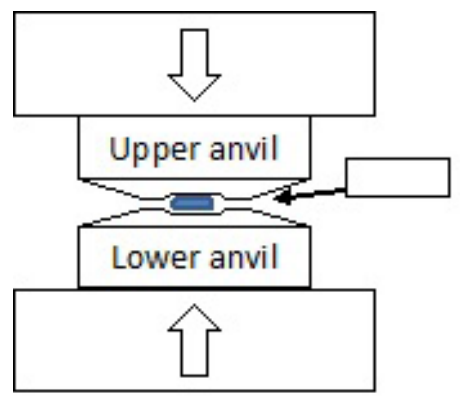

Fig. 1. Schematic of HPT consolidation.

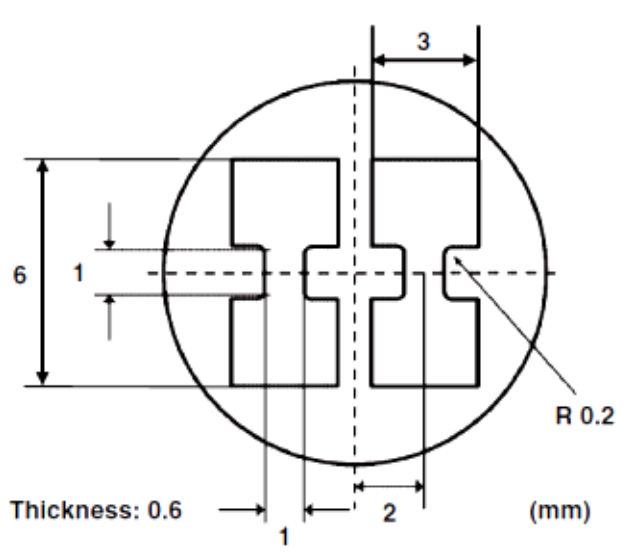

Fig. 2. Schematic of cutting the miniature tensile samples. 


\section{Results and Discussion}

\subsection{Initial microstructure}

Initial TEM microstructure of RQ and RQ+ HPT nickel specimens are shown in Fig. 3a,b, respectively. Thus, the microstructure of the RQ nickel is fine with a mean grain size of $\sim 1-2 \mu \mathrm{m}$, the grains are separated by well-defined boundaries with fringes indicating that the boundary dislocation density is high and some retained dislocations are observed in grain interiors as shown in Fig. 3a. Some a

of the grain interiors of the RQ nickel are essentially free of dislocations. By contrast, the RQ+ HPT microstructure in Fig. 3b shows a typical highly strained microstructure with a mean grain size of less than $100 \mathrm{~nm}$. The selected area electron diffraction (SAED) pattern in the upper right is similar to that observed for HPT metals $[1,3]$. However, one can notice that HPT consolidated RQ nickel possesses relatively better defined microstructure with well resolved grain boundaries with Moiré fringes.

\subsection{Tensile testing}

b

Engineering stress - strain curves obtained at a constant strain rate of $10^{-3} \mathrm{~s}^{-1}$ and an elongation to fracture are shown in Fig. 4. A specimen fractured at room temperature was brittle and quite probably porous which may cause low strength of nickel specimen tested at room temperature
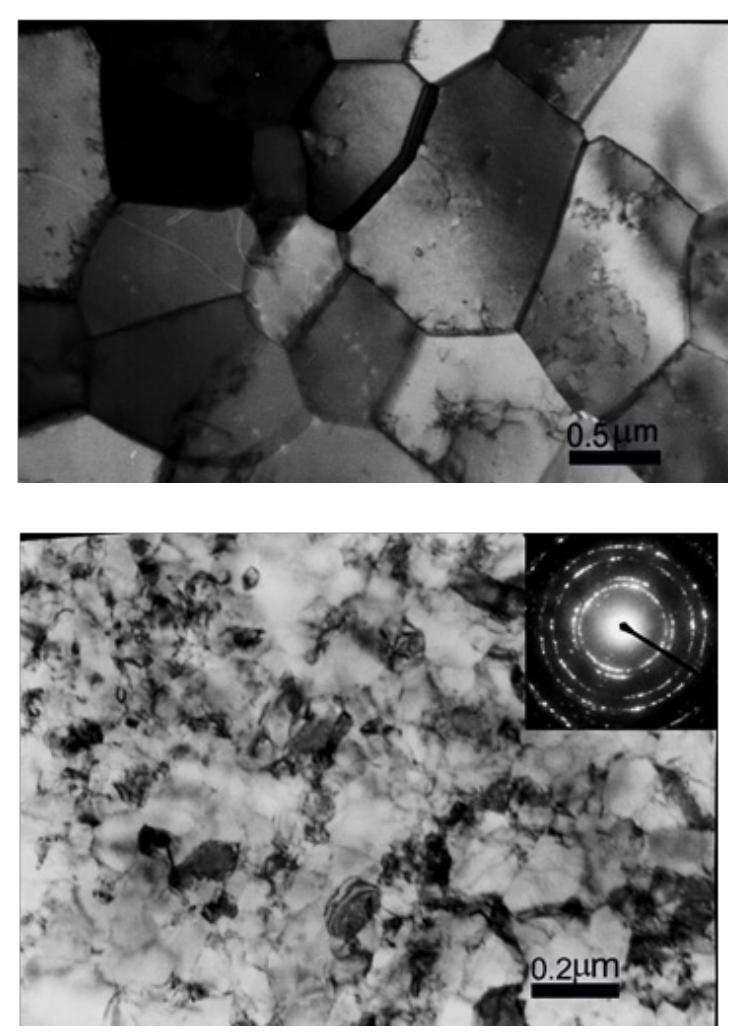

Fig. 3. Microstructure of nickel: (a) rapid quenched ribbons and (b) HPT consolidated RQ ribbons.
(Fig. 4a). An important transition in mechanical behavior occurred above RT, indicated by the $250^{\circ} \mathrm{C}$-curve that shows yielding and strong strain hardening with a double increase in elongation to fracture. It shows high strength of $900 \mathrm{MPa}$ greater that NC electrodeposited nickel $(<400 \mathrm{MPa})$ tested at the same condition [5]. Increasing testing temperature significantly improved ductility of HPT consolidated RQ nickel up to $140 \%$ at testing temperature of $450^{\circ} \mathrm{C}$. Fig. $4 \mathrm{~b}$ shows the elongation to fracture as a function of testing temperature. It is worth to notice that there is a transition region of $250-350^{\circ} \mathrm{C}$ from low to high ductility. This transition coincides with exothermic peak in the DSC curve obtained in $[5,15]$ for electrodeposited nickel and it was assumed that it is associated with abnormal grain growth in nanocrystalline nickel giving rising in grain size of $1-2$ order of magnitude. This phenomenon of abnormal grain growth may be a mechanism for accommodation of grain boundary sliding during superplastic deformation in case of electrodeposited nickel. However, in case of HPT consolidated rapid quenched nickel ribbons has shown no superplastic properties (elongation $>200 \%$ ) and superplastic regime has not been attained at testing temperature of $450^{\circ} \mathrm{C}$. According to deformation map [16] deformation mechanism in this case is power-law creep by climb-plus-glide or power-low creep limited by gliding alone.

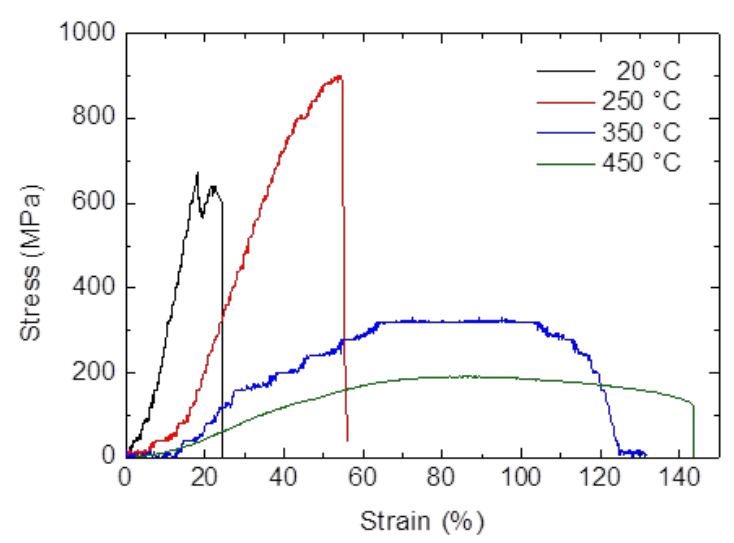

a

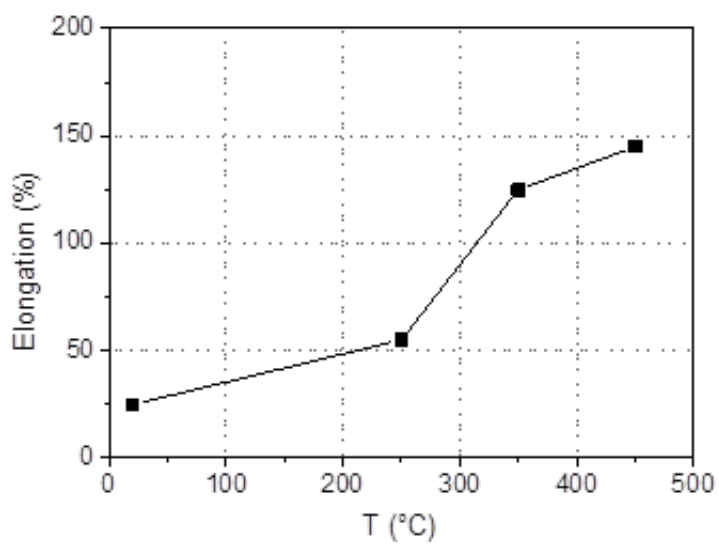

$\mathrm{b}$

Fig. 4. (a) Engineering stress-strain curves for HPT consolidated RQ nickel tested at elevated temperatures $\left(\dot{\varepsilon}=10^{-3} \mathrm{~s}^{-1}\right)$; (b) Elongation to fracture as a function of testing temperature. 


\subsection{Thermal stability}

In order to inspect a microstructure of the nanostructured nickel at start of tensile test some specimens were heated up at the same heating rate $\left(50^{\circ} / \mathrm{min}\right)$ to the test temperature of 250,350 and $450^{\circ} \mathrm{C}$. TEM microstructure (bright field images) is depicted in Fig. 5. An evaluation gives the values of mean grain size $\sim 80 \mathrm{~nm}, \sim 110 \mathrm{~nm}$ and $\sim 150 \mathrm{~nm}$ for specimens heated up to 250,350 and $450^{\circ} \mathrm{C}$, respectively. Unlike electrodeposited nanonickel there is normal grain growth during annealing to the test temperature.

\subsection{Power exponents}

Differentiating of equation (1) and plotting functions

$$
\ln \left(\frac{\sigma}{E}\right) \text { vs. } \ln \left(\frac{b}{d}\right) \text { and } \ln \left(\frac{\sigma}{E}\right) \text { vs. } \frac{1000}{T}
$$

From first equation (2) by plotting one can estimate exponents $p$ (Fig. 6a). For our experiments $p$ equals approximately 2.5 , giving close value of 2 observed in superplastic regime. Second equation is shown in Fig. $6 \mathrm{~b}$. From slope stress exponent $n=1 / m \sim 0.2$ can be estimated suggesting that GB diffusion is controlling process and $Q_{\mathrm{GB}}=115 \mathrm{~kJ} / \mathrm{mol}$ is activation energy for this process [16].

\section{Concluding Remarks}

Bulk ultrafine-grained nickel was successfully processed by RT consolidation of rapid quenched ribbons using high-pressure torsion. RQ nickel possesses equiaxed grain structure with mean grain size of $1-2 \mu \mathrm{m}$ showing well defined grain boundaries. Upon HPT consolidation mean grain size of $\sim 0.2 \mu \mathrm{m}$ and high dislocation density have been achieved. However, consolidated $\mathrm{Ni}$ specimens show enhanced plasticity $>140 \%$ at testing temperature of $450^{\circ} \mathrm{C}$ and strain rate of $10^{-3} \mathrm{~s}^{-1}$. No superplastic regime has been attained for given testing conditions.

\section{References}

1. R.Z. Valiev, A.P. Zhilyaev, T.G. Langdon. Bulk nanostructured materials: Fundamentals and applications. Wiley \& Sons, New Jersey, 2014.

2. R.Z. Valiev, T.G. Langdon. Principles of equal-channel angular pressing as a processing tool for grain refinement. Prog. Mater. Sci. 51, 881—981 (2006).

3. A. P. Zhilyaev, T. G. Langdon. Using high-pressure torsion for metals processing: fundamentals and applications. Prog. Mater. Sci. 53, 893-979 (2008).

4. S.X. McFadden, R.S. Mishra, R.Z. Valiev, A.P. Zhilyaev,

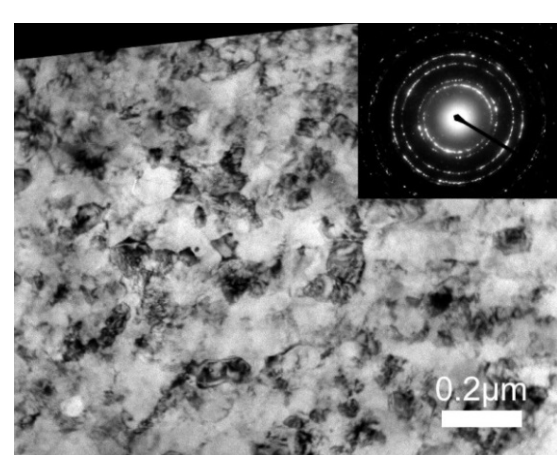

a

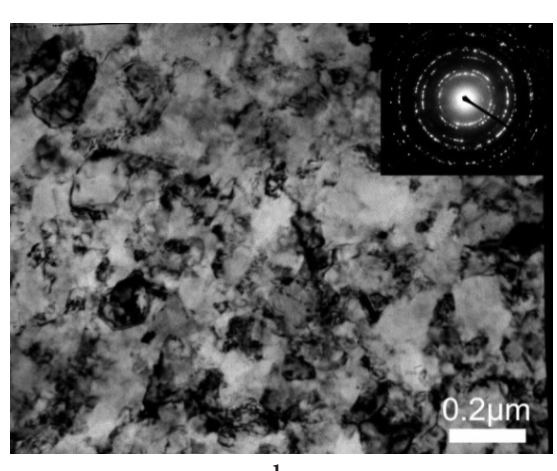

b

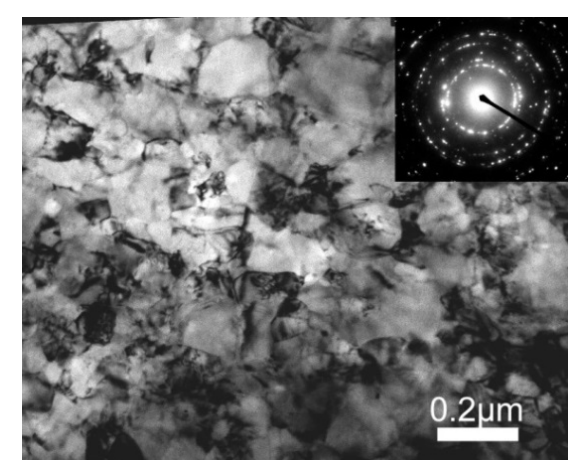

C

Fig. 5. TEM microstructure of HPT consolidated RQ nickel at the start of test condition: (a) $250^{\circ} \mathrm{C}$; (b) $350^{\circ} \mathrm{C}$ and (c) $450^{\circ} \mathrm{C}$.

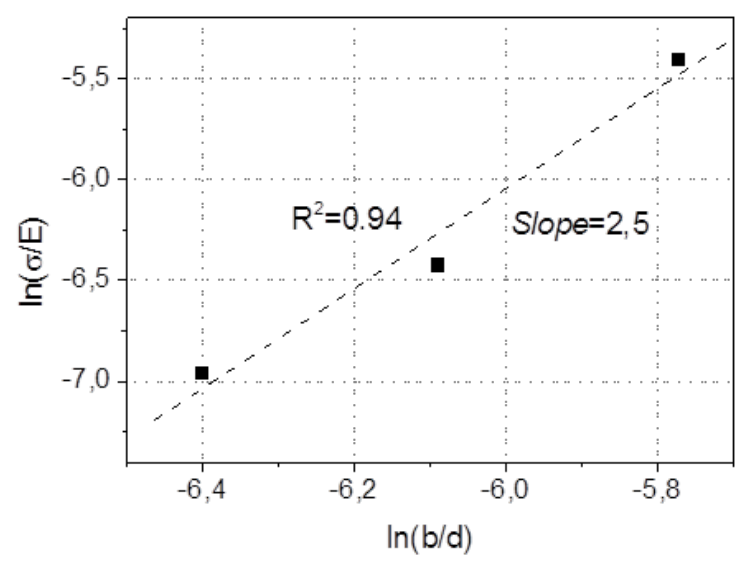

a

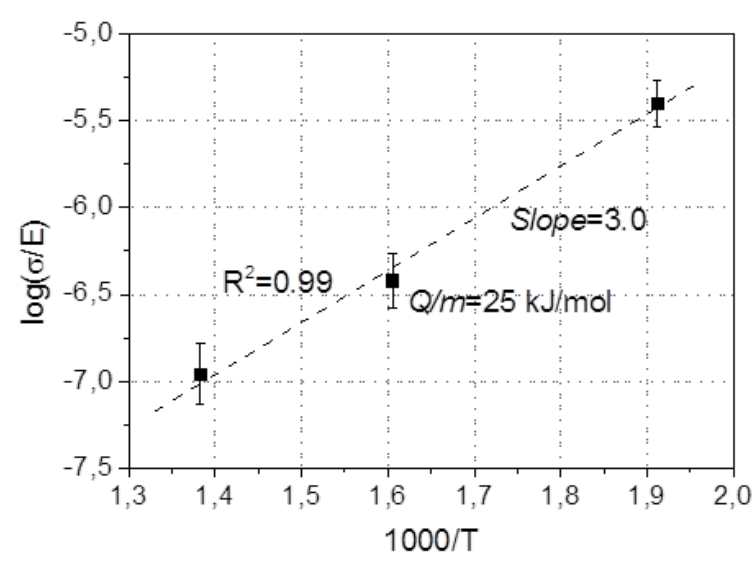

$\mathrm{b}$

Fig. 6. $\log (\sigma / E)$ as function of inverse (a) grain size and (b) testing temperature (1/T). 
A.K. Mukherjee. Low-temperature superplasticity in nanostructured nickel and metal alloys. Nature. 398, 684-686 (1999).

5. S.X. McFadden, A.P. Zhilyaev, R.S. Mishra, A.K. Mukherjee. Observations of low-temperature superplasticity in electrodeposited ultrafine grained nickel. Mater. Let. 45, 345-349 (2000).

6. A.P. Zhilyaev. Superplasticity and microstructure evolution in nanonickel. Mater. Phys. Mech. 1, 98-102 (2000).

7. A.P. Zhilyaev, A.I. Pshenichnyuk Superplasticity and grain boundaries in ultrafine-grained materials. Cambridge Intern. Sci. Publ., Cambridge, 2010.

8. S.X. McFadden, A.K. Mukherjee. Sulfur and superplasticity in electrodeposited ultrafine-grained Ni. Mater. Sci. Eng. A 395, 265-268 (2005).

9. M. J. N. V. Prasad, A.H. Chokshi. Superplasticity in electrodeposited nanocrystalline nickel. Acta Mater. 58, 5724-5736 (2010).

10. M.J. N. V. Prasad, A.H. Chokshi. Extraordinary high strain rate superplasticity in electrodeposited nano-nickel and alloys. Scripta Mater. 63, 136-139 (2010).

11. M. J. N. V. Prasad, A.H. Chokshi. Deformation-induced thermally activated grain growth in nanocrystalline nickel. Scripta Mater. 67, 133-136 (2012).

12. A.P. Zhilyaev, A. A Gimazov, E. P. Soshnikova, A. Révész, T. G. Langdon. Microstructural characteristics of nickel processed to ultrahigh strains by high-pressure torsion. Mater. Sci. Eng. A 133-136, 207-212 (2008).

13. K.S. Kumar, S. Suresh, M.F. Chisholm, J.A. Horton, P. Wang. Deformation of electrodeposited nanocrystalline nickel. Acta Mater. 51, 387-405 (2003).

14. K. S. Kumar, H. Van Swygenhoven, S. Suresh. Mechanical behavior of nanocrystalline metals and alloys. Acta Mater. 51, 5743-5774 (2003).

15. N. Wang, Z. Wang, K. T. Aust, U.Erb. Isokinetic analysis of nanocrystalline nickel electrodeposits upon annealing. Acta Mater. 45, 1655-1669 (1997).

16. H. J. Frost, M.F. Ashby. Deformation-Mechanism Maps, The Plasticity and Creep of Metals and Ceramics. Pergamon Press, Oxford, 1982. 